\title{
The Development of Agricultural Supply Chain Finance in Jinan
}

\author{
Leng bingxin ${ }^{1, a}$, Huang Ying ${ }^{2, b}$ Shen Fei ${ }^{3, c}$ \\ ${ }^{1}$ Student of financial risk and management, Business school, University of Jinan, Shandong, China \\ ${ }^{2}$ Business School, University of Jinan, Shandong, China \\ ${ }^{3}$ Social Research Institute of Jinan, Shandong, China \\ a1303936484@qq.com, bhuang-yin-2000@163.com, ${ }^{\mathrm{c}} 643489276 @ q q . c o m$
}

Keywords: Jinan Agricultural Supply Chain Finance, Agriculture-related Loans

Abstract. The mode of agricultural supply chain financial applies supply chain finance in the agricultural industry chain, which can effectively solve the financing difficulties of farmers and the rural financial repression issues. We researched the development of Jinan`s agricultural financial supply chain and analyzed agriculture-related loans data of Rural credit cooperatives in Jinan. In this paper, we explored into the main four modes of the Jinan`s agricultural supply chain finance and proposed suggestions for constructing agricultural supply chain in Jinan.

\section{Introduction}

Agricultural supply chain finance is a financial institution serving the rural, which depends on the agricultural supply chain to increase corporate credit, effectively supervise the quality and production of agricultural products. This mode can solve weak regulatory functions of the core agricultural enterprises, unreasonable management of agricultural financing, loans dispersed, and agricultural industry development without planning system and other issues. To speed up the industrialization of agriculture and rural economic development in Jinan, we should improve and perfect the Jinan`s agriculture supply chain financial model without delay.

\section{Introduction of the Industrialization of Agriculture in Jinan}

In recent years, Jinan`s rural economic development momentum is good. By the end of 2015, rural per person net income reached 15,978 RMB, which increased 8.5 percent over the previous year. Jinan`s also strive to promote the development of a variety of economies and mode of business operation, in which core agricultural enterprises, farmer cooperatives and family farms to 536, 5552and $1276 .{ }^{[1]}$

\section{Jinan's Rural credit cooperatives agricultural loans data analysis}

\section{The structure of agriculture-related loans}

According to survey data of Jinan`s rural credit cooperatives in 2013 ,farmers loans is mainly agriculture-related loans amounting to 14 billion RMB accounting for $81 \%$ of total loans, which is followed by the rural economic corporations in the amount of 2.26 billion RMB accounting for the 13\%; and finally the urban corporations loans is 1.1 billion RMB. It follows that agricultural enterprises, farmer cooperatives and other agricultural organizations do not effectively combined with individual farmers. The main interaction through purchase and supply of agricultural products, so rural financial supply chain is still imperfect. ${ }^{[2]}$ 


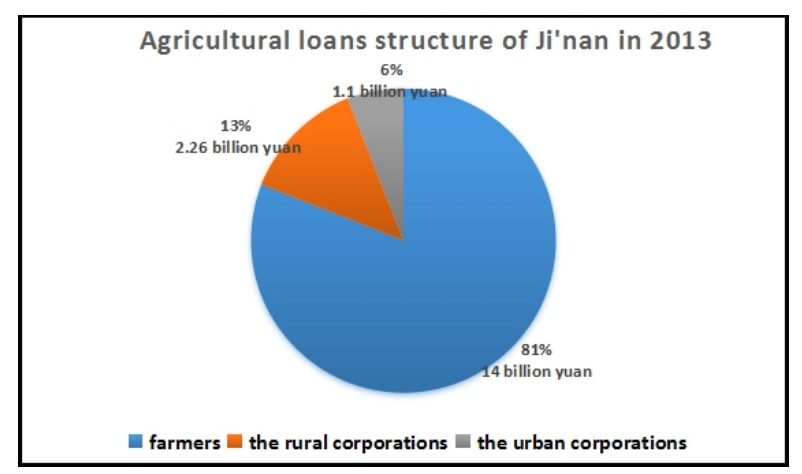

Table 1.

\section{The growth of agriculture-related loans}

According to the Rural credit cooperatives statistical data in 2008-2013, it can be seen that agriculture-related loan growth rate has a sharp increase from 2008 to 2010 , which increased in $16 \%$. However, there was a speed decline beginning in 2011.It was only $0.3 \% 2$ years later. This is entirely conflict with the national agricultural policy in recent years. The government of Jinan vigorously promotes the reform of rural mechanization optimizing agricultural basic construction. Agriculture-related loans should theoretically increase greatly.

\begin{tabular}{|l|l|l|l|}
\hline \multicolumn{1}{|l}{ Ji'nan rural credit cooperatives 2008-2013 agricultural loans growth } \\
\hline years & $\begin{array}{l}\text { agriculture-related loans } \\
\text { (billion yuan) }\end{array}$ & $\begin{array}{l}\text { Amount of loans added } \\
\text { (billion yuan) }\end{array}$ & Increase rate \\
\hline 2008 & 11.9 & 1.46 & $12 \%$ \\
\hline 2009 & 13.84 & 1.94 & $14 \%$ \\
\hline 2010 & 16.54 & 2.7 & $16 \%$ \\
\hline 2011 & 17.1 & 0.56 & $3 \%$ \\
\hline 2012 & 17.3 & 0.2 & $1 \%$ \\
\hline 2013 & 17.36 & 0.06 & $0.30 \%$ \\
\hline
\end{tabular}

Table 2.

\section{Reasons for the slow growth of agriculture-related loans}

Profound Changes in Structure of Rural Production in Jinan

The economic structure of Jinan is pretty special. The development of the secondary and tertiary industries is far higher than the primary industry. Moreover, economy of urban is much higher than the county. The urban resident population of 3.88 million accounts for $57 \%$ of the total population. The country amounts 2.91 million accounting for $43 \%$ of the total population. The primary industry GDP contribution rate is 18 per cent. Secondary and tertiary industries contributed more than $80 \%$. In recent years, Jinan`s municipal government will strive to build a modern industrial system. And it accelerates the development of services, cultural industries and other tertiary industries. For agriculture, the Jinan`s municipal government proposed to strengthen environmental protection and the establishment of modern urban agriculture. Therefore, agriculture gradually fades in the traditional sense.

Significant changes in credit demand and customer groups

With the process of the urban-rural integration, agricultural industry structure has undergone great changes. Traditional agriculture and modern agriculture will coexist for a long period of time. According to survey data of the rural credit cooperatives, the traditional agriculture accounted for $64 \%$, the basic realization of the industrialization of agriculture accounted for $36 \%$. According to rural credit cooperatives research report, the farmers' early and sustainable investments are summarized as follows: 


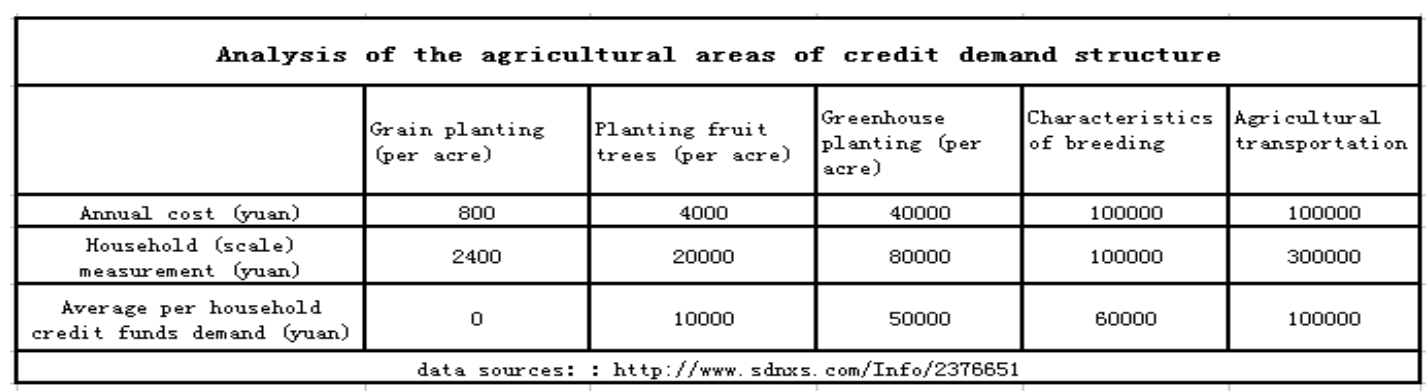

Table 3.

In summary, the current tradition and industrialization of agriculture planting, breeding and transportation funding needs most can be solved and satisfied by its own funds (deposits, loans friends and relatives). Traditional agricultural farming households do not need credit funds. Agricultural industrialization of farmers' loan funds demand ratio is $40 \%$, the loan amount is concentrated in the 5-10 million, more than 200 thousand RMB of farmers' loans actually rare used for farming, processing, and transportation industry demand.

At present, from the customer's own conditions, some types of customer loans repay debt, whose guarantee ability are limited. They have been unable to get more credit funds. According to the survey, it found that a considerable part of farmers use agricultural loans to do individual business. Besides, they use private lending, it is difficult to effectively monitor, which increased NPL ratio. Since 2008, the Jinan`s credit cooperatives personal non-performing loans increased by more than one billion RMB, in which over 300 thousand RMB farmers loans increased by more than $80 \%$. According to the Shandong province's agricultural credit system, the non-performing loan rate of farmers is $9.76 \%$ in Jinan`s, which is higher than the Shandong province's average level of 1.61 percentage points.

\section{Financial Mode of Agricultural Supply Chain in Jinan and its Improvement}

\section{Operation mode "Farmers + Agricultural enterprises + Bank"}

The farmers sell their crops to agricultural enterprises for their personal loans. Farmers are recommended by the agricultural enterprises to submit loan applications for the bank . Agricultural enterprises provide security for farmers loans, and loan funds are paid to agricultural enterprises doing a unified regulation and management, which enhance the security of the loan. ${ }^{[3]}$

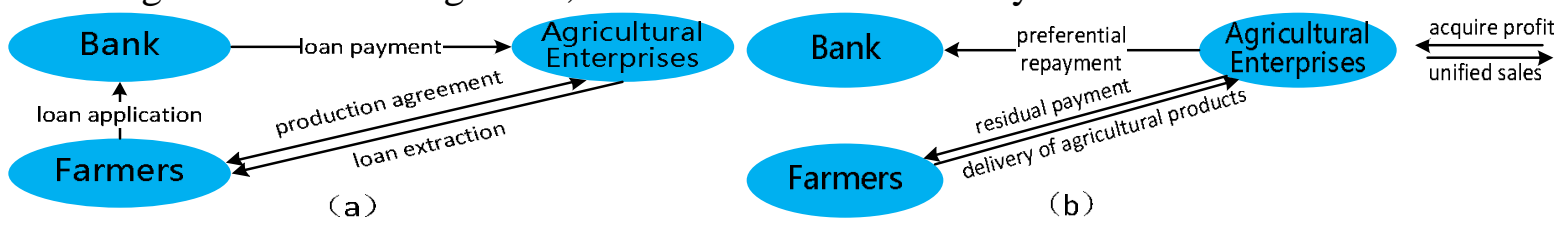

Fig1. Operation mode "Farmers + agricultural enterprises + bank"

\section{Operation mode "Farmers + Agricultural base + Agricultural enterprises + Bank"}

"Farmers + Agricultural base +Agricultural enterprises + Bank" model is applied to the agricultural base in Jinan, which provides an effective supervision mechanism for agricultural enterprises to ensure the quality and production. Such as Jinan`s Green Spring Co., Ltd., it was built with efficient agricultural base to form plant seedling production, standardization of green vegetable production in the two main industry. ${ }^{[4]}$

Its financial chain mainly relies on bank credit assessment to provide financing by farmer's credit. Agricultural base sign a regulatory agreement, and monitor production and sale agricultural products. Farmers use resources of agricultural base and technical advantages during the unified guidance of agricultural enterprises to carry out daily agricultural production. Moreover, product centralized delivery to agricultural enterprises in charge of sales. 


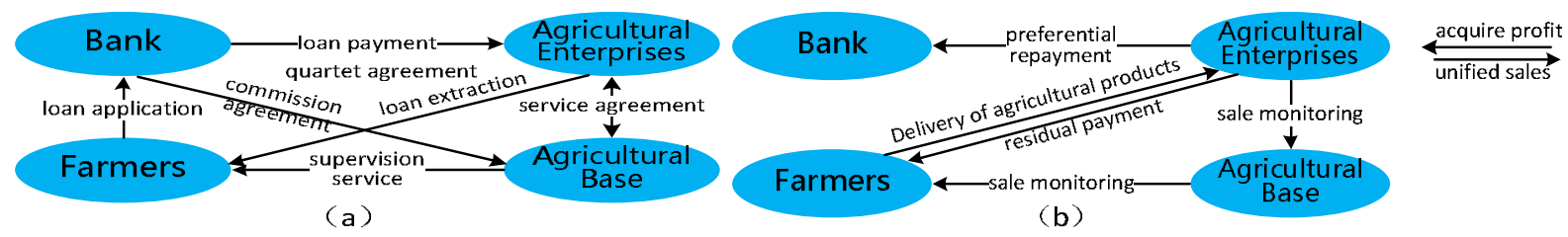

Fig2. Operation mode "Farmers + Agricultural base + Agricultural enterprises + Bank"

The advantages of this model are (1) For farmers, farmers can mortgage agricultural products to agricultural enterprises, which can increase the amount of agricultural loans and reduce interest payments; (2) The agricultural bases can provide advanced technology and help the agricultural enterprises to supervise the production and sales of agricultural products; (3) For the agricultural enterprises, they can save the cost and reduce the operational risk of the enterprise through the agricultural products agreement. The disadvantages are that: (1) the farmers are not controllable risk factors. Agricultural bases can not accurately measure the risk of each individual in the farmer group;

(2) each farmer individual is guaranteed by the agreement of the enterprise and apply for the loan by the bank, its procedure is complex, the efficiency is low, the process is troublesome.

\section{Operation mode "Farmers + Farmer cooperatives + Agricultural enterprises + Bank"}

"Farmers + Farmer cooperatives + Agricultural enterprises + Bank" mode of operation should be used for the intensive and large-scale production and operation of farmer cooperatives. For example, Jinan`s ecological sightseeing agriculture cooperatives unified planed to promote the villagers' income. The establishment of farmers' cooperatives not only get the city funds, technology, personnel support and all the villagers achieve entrepreneurial wealth. ${ }^{[5]}$

In this model, banks, farmers, agricultural enterprises, farmer cooperatives signed four agreements. Farmers' cooperatives are the loan subject, and the agricultural enterprises assume joint responsibility. Bank loans are paid to farmer cooperatives account, which is responsible for the reasonable expenses of agricultural production process and prepare the daily payment details. At the same time, it is responsible for the management of farmers and provides some technical support. After the harvest of agricultural products, agricultural cooperatives delivered to the agricultural enterprises. The latter unified sales to customers, farmer cooperatives have priority to repay loans of financial institutions and then distribute farmer's profits.

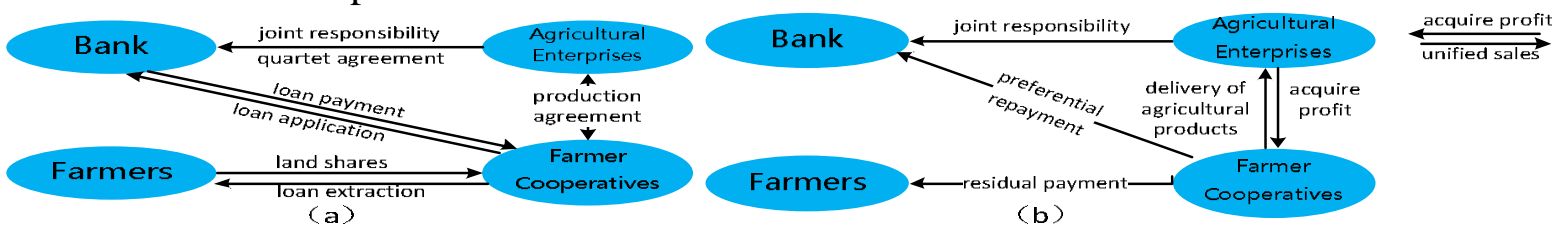

Fig.3. Operation mode "Farmers + Farmer cooperatives + Agricultural enterprises + Bank"

The advantage of this model is the main bank borrowing transform the decentralized into mass, which effectively reducing the cost and risk of bank credit. At the same time, farmers can not mortgage the land as collateral to solve the difficulties of farmers lack collateral. Its main drawback is that the agricultural production cooperatives are a voluntary union of farmers, which manage and support relatively scarce. It can not make the fullest use of labor and land.

\section{Operation mode "Farmers + Agricultural cooperatives + Agricultural base + Agricultural enterprises + Bank"}

"Farmers + Agricultural cooperatives + Agricultural base + Agricultural enterprises + Bank" agricultural supply chain financial model is a new supply chain financial model, which does not appear in Jinan. 


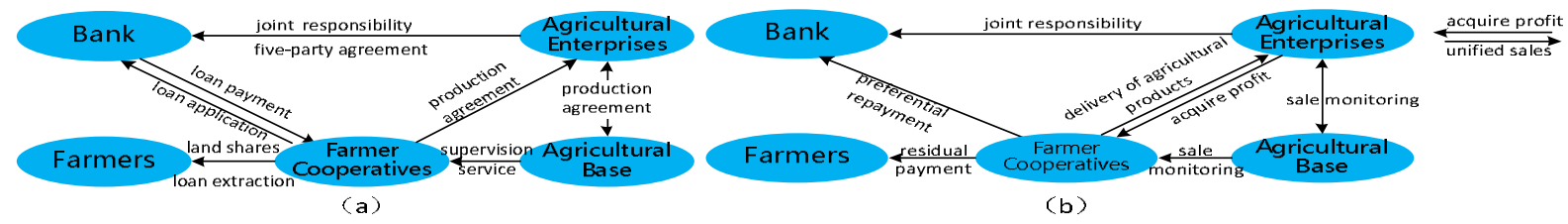

Fig4. Operation mode "Farmers + Agricultural cooperatives + Agricultural base + Agricultural enterprises + Bank"

Compared with the above three kinds of development models of agricultural supply chain, this supply chain effectively solves the above three modes' troubles. Combining its advantages, they make the rural financial supply chain development mode more perfect and effective. Its advantages are: (1) For farmers, the farmer cooperatives unify loan applications with a high amount, which are fast and safe procedures. In addition to the agricultural bases provide professional technical support and rich experience of management to minimize the risk of crop production.(2) For the farmer cooperatives and agricultural bases, on the one hand, they avoid the lack of mechanization of farmer cooperatives, and on the other hand, it solve the problem of the management and coordination of the individual farmers.(3) For agricultural enterprises, they are directly related to the farmer cooperatives to achieve effectively supervision and avoid the risk of business. (4) For banks, the agricultural supply chain model reduces the risk of loan default and increases the bank earnings.

\section{Conclusions}

To sum up, "Farmers + Agricultural cooperatives + Agricultural base + Agricultural enterprises + Bank" mode of operation can improve the credibility of the Jinan`s farm loans and reduce the rate of bad loans of Jinan`s bank of agriculture-related loans. In order to improve the development of Jinan`s rural supply chain financial model, banks should strengthen financial innovation and improve the financial service model. And it also should accelerate the reform and innovation of rural financial system according to the Jinan`s rural areas situation and farmers need.

\section{References}

[1] Information on http://www.jinan.gov.cn/art/2015/12/14/art_143_358726.html

[2] Information on http://www.sdnxs.com/Info/2376651

[3] Guohui Hu, Meng Zheng: Study on the operation mode and income distribution of agricultural supply chain finance (2013)

[4] Information on http://www.shanghe.gov.cn/art/2011/12/9/art_2071_37896.html

[5] Information on http://www.jnny.gov.cn/details/details.asp?id=2017 